\title{
PENGARUH BUDAYA KERJA TERHADAP PRODUKTIVITAS KERJA PEGAWAI PADA SEKRETARIAT DPRD KABUPATEN PESAWARAN
}

\author{
Rio Hardono ${ }^{(1)}$, Husna Purnama ${ }^{(2)}$, Khairul Saleh $^{(3)}$ \\ Fakultas Ekonomi Universitas Sang Bumi Ruwa Jurai \\ hardono.rio_14@gmail.com, husna.purnama@fe.saburai.ac.id, khairul.saleh@fe.saburai.ac.id
}

\begin{abstract}
Abstrak. Sekretariat DPRD Kabupaten Pesawaran berupaya meningkatkan produktivitas kerja pegawai melalui penerapan budaya kerja. Masalah yang dihadapi berupa kurang optimalnya budaya kerja adalah penyelesaian pekerjaan yang tidak tepat waktu, loyalitas pegawai terhadap pekerjaan yang mulai berkurang, dan kurangnya kerja sama antar pegawai dalam menyelesaikan pekerjaan. Hal-hal tersebut mengindikasikan kurang berjalannya budaya kerja sehingga berdampak menurunya produktivitas kerja. Teknik pengumpulan data yang digunakan adalah observasi, wawancara, dokumentasi dan quisioner/ daftar pertanyaan dari jumlah populasi sebanyak 19 orang responden Sekretariat DPRD Kabupaten Pesawaran. Berdasarkan analisa kuantitatif diperoleh dari hasil perhitungan pengaruh Budaya kerja (X) terhadap Produktivitas kerja (Y) secara parsial menunjukan bahwa Nilai $t$ hitung variabel budaya kerja yaitu 2,485, $t$ tabel diperoleh 1,729 karena $t_{\text {hitung }}>t_{\text {tabel }}$ maka Ha diterima. Artinya budaya kerja berpengaruh positif terhadap produtivitas kerja pegawai Sekretariat DPRD Kabupaten Pesawaran. Berdasarkan hasil pengujian hipotesis budaya kerja berpengaruh positif dan signifikan terhadap produktivitas kerja pegawai.
\end{abstract}

Kata kunci: Budaya, Kerja, Pengaruh, Produktivitas.

\section{PENDAHULUAN}

Pembangunan Sumber Daya Manusia adalah upaya untuk mendapatkan pegawai yang berkualitas tinggi dengan cara meningkatkan sumber daya pegawai pemerintah. Yang dapat dilihat dari kompetensinya sehingga dapat mengahasilkan suatu pegawai pemerintah yang efektif. Sumber Daya manusia adalah aset yang sangat berharga dan merupakan salah satu faktor penting dalam menunjang keberhasilan pelaksanaan kegiatan suatu organisasi, baik organisasi pemrintahan maupun organisasi swasta.

Hal ini disebabkan karena manusia memiliki kemampuan untuk berkembang secara rasional dan juga mempunyai kemampuan untuk berkembang secara terus menerus dan berkesinambungan. Karena pegawai pemerintahan memberikan kontribusi yang sangat besar bagi organisasi dalam proses pencapaian tujuan yang telah ditetapkan. Untuk mempersiapkan segala sesuatu agar menjadi lebih efektif dan untuk memperbaiki sikap dan perilaku kerja para pegawai agar dapat menghasilkan pegawai yang memiliki produktivitas yang tinggi.

Produktivitas merupakan sebuah alat rangkuman tentang jumlah dan kualitas performa pekerjaan, dengan mempertimbangkan pemanfaatan sumbersumber daya. Filosofi mengenai produktivitas mengandung arti keinginan dan usaha dari setiap manusia untuk selalu meningkatan mutu kehidupan dan penghidupannya. Pandangan memberi semangat cukup mendalam dan memungkinkan orang yang memahaminya memandang kerja, baik secara individual maupun berkelompok dalam suatu organisasi sebagai suatu keutamaan.

Salah satu faktor yang mempengaruhi produktivitas kerja dalam suatu organisasi adalah budaya kerja, dimana faktor tersebut 
sangat erat kaitannya dalam meningkatkan kinerja pegawai, sebab dengan terciptanya budaya kerja yang baik dan ditunjang oleh kerja sama dengan sesama pegawai, maka akan tercapai hasil yang dapat meningkatkan kinerja kerja pegawai.

Budaya kerja adalah cara kerja seharihari yang bermutu dan selalu mendasari nilai-nilai yang penuh makna, sehingga menjadi motivasi, memberi inspirasi, untuk senantiasa bekerja lebih baik dan memuaskan bagi masyarakat yang dilayani. Kuatnya budaya kerja akan terlihat dari bagaimana pegawai memandang budaya kerja sehingga berpengaruh terhadap perilaku yang digambarkan antara lain memiliki motivasi, dedikasi, kreatifitas, kemampuan dan komitmen yang tinggi. Semakin kuat budaya kerja , semakin tinggi komitmen dan kemampuan yang dirasakan pegawai . Makin banyak pegawai yang menerima nilai-nilai makin tinggi kemampuan dan komitmen mereka pada nilai-nilai itu dan semakin kuat budaya tersebut.

Budaya kerja pada umumnya merupakan pernyataan filosofis, dapat difungsikan sebagai tuntutan yang mengikat para pegawai karena dapat diformulasikan secara formal dalam berbagai peraturan dan ketentuan organisasi . Dengan membakukan budaya kerja , sebagai suatu acuan bagi ketentuan atau peraturan yang berlaku, maka para pemimpin dan pegawai secara tidak langsung akan terikat sehingga dapat membentuk sikap dan perilaku sesuai dengan visi dan misi serta strategi. Proses pembentukan tersebut pada akhirnya akan menghasilkan pemimpin dan pegawai professional yang mempunyai integritas yang tinggi.

Oleh karena itu pimpinan harus berusaha menciptakan kondisi budaya kerja yang kondusif dan dapat mendukung terciptanya kinerja yang baik dalam menciptakan budaya kerja yang diinginkan atau budaya yang kuat maka upaya yang ingin dicapai adalah untuk menciptakan budaya kerja yang baik, sehingga dapat meningkatkan kinerja para pegawai.

Hal ini dapat dilihat pada penerapan budaya kerja pada pegawai Sekretariat DPRD Kabupaten Pesawaran belum optimal, dimana masih ada pegawai yang tidak mematuhi jam kerja, disamping itu sikap pegawai yang tidak memegang teguh amanah dalam melaksanakan tugas pokok dan kewajibannya sebagai pegawai . Tindakan-tindakan seperti tersebut di atas dapat berakibat pada kurangnya produktivitas kerja pegawai.

Sekretariat DPRD Kabupaten Pesawaran merupakan lembaga pemerintah Daerah Kabupaten Pesawaran. Dalam mencapai tujuan organisasi berupa pencapaian kinerja pegawai dihadapkan pada kendala-kendala berupa kehadiran pegawai yang menurun, penyelesaian pekerjaan yang tertunda, kurangnya kerjasama antar pegawai dalam penyelesaian pekerjaan, pelaksanaan pekerjaan yang kurang terarah serta pengelolaan manajemen personalia yang belum disesuaikan dengan bidang pekerjaan. Berbagai kendala tersebut disebabkan oleh kendala berupa kurang berjalannya budaya kerja .

Berdasarkan beberapa hal yang disebutkan, maka penulis tertarik meneliti lebih lanjut dengan judul: "PENGARUH BUDAYA KERJA TERHADAP PRODUKTIVITAS KERJA PEGAWAI PADA SEKRETARIAT DPRD KABUPATEN PESAWARAN".

\section{KAJIAN TEORI}

\section{Budaya Kerja}

Budaya: Berasal dari bahasa Sansekerta, budhayah yang berarti hal-hal yang bersangkutan dengan akal atau segala sesuatu yang berkaitan dengan akal pikiran, 
nilai-nilai dan sikap mental. Kemudian berkembang sebagai cara manusia mengaktualisasikan nilai (value), karsa (creativity) dan hasil karyanya (performance) (Kementerian PAN, 2002).

Pada suatu organisasi yang mempunyai sarana untuk mencapai suatu tujuan, budaya pada umumnya diwujudkan dalam bentuk kinerja kerja. Bentuk aktualisasinya dalam nilai-nilai, sehingga dalam suatu kesatuan menjadi suatu nilai budaya kerja. Pengertian budaya kerja organisasi adalah cara kerja sehari-hari yang bermutu dan selalu mendasari nilai-nilai yang penuh makna, sehingga menjadi motivasi, memberi inspirasi untuk senantiasa bekerja lebih baik, dan memuaskan bagi masyarakat yang dilayani (Kementerian PAN, 2008).

Pada konteks pemerintahan atau aparaturnya budaya kerja diartikan sebagai cara pandang atau cara seseorang memberikan makna terhadap "kerja", maka dapat dipahami sebagai cara pandang serta suasana hati yang menumbuhkan keyakinan yang kuat atas dasar nilai-nilai yang diyakininya, serta memiliki semangat yang tinggi dan bersungguh-sungguh untuk mewujudkan prestasi terbaik (Kementerian PAN, 2008).

\section{Prinsip-Prinsip Budaya Kerja}

Prinsip-prinsip budaya kerja sebenarnya merupakan hal-hal yang dasar yang dilakukan dalam suatu pelaksanaan kerja. Kerja sebenarnya merupakan suatu proses penciptaan nilai pada suatu unit sumber daya. Terdapat beberapa nilai yang bisa menjadi prinsip budaya kerja, yaitu :

1. Etos kerja, merupakan watak atau semangat fundamental suatu budaya, berbagai ungkapan yang menunjukkan kepercayaan, kebiasaan, atau perilaku suatu kelompok masyarakat. Etos merupakan komponen budaya yang merupakan kekuatan pendorong atau penggerak, sehingga manusia siap kerja keras. Etos kerja dapat diukur dengan tinggi rendah, kuat (keras) atau lemah, tidak dengan baik buruknya atau benar salahnya.

2. Workaholism, sebagai bagian dari budaya kerja, hal tersebut karena menunjukkan salah satu pola dan kualitas perilaku manusia dalam bekerja, baik secara pribadi, pekerjaan dinas, kelompok, bebas atau kompetitif. Workaholism bisa berdampak positif dan sebaliknya, baik kepada pelaku atau hasil dari kerjaan yang dilakukan.

3. Etika kerja, merupakan peristiwa rohani yang berkaitan dengan kalbu atau nurani manusia-manusia, ketika dihadapkan pada pilihan, memilih dengan bebas, membuat keputusan batin dan bertanggung jawab atas pilihannya.

4. Anggapan dasar tentang kerja, merupakan kesimpulan dalam bentuk pendirian Kerja dapat diartikan sebagai hukuman, upeti, beban, kewajiban, sumber penghasilan, kesenangan, status, prestise atau gengsi, harga diri, aktualisasi diri, panggilan jiwa, pengabdian, hak atau sebaliknya, hidup atau sebaliknya dan ibadah serta suci.

\section{Fungsi Budaya Kerja}

Fungsi budaya kerja organisasi pemerintah oleh aparatur Negara tercermin dari cara kerja sehari-hari yang bermutu dan selalu mendasari nilai-nilai yang penuh makna, sehingga menjadi motivasi, memberi inspirasi untuk senantiasa bekerja lebih baik dan memuaskan bagi masyarakat yang dilayani (Kementerian PAN, 2002). Fungsi-fungsi tersebut adalah sebagai culture in action, way of thinking, way of life yang perwujudannya antara lain : 
1. Sebagai identitas dan citra suatu masyarakat Sebagai pengikat suatu masyarakat

2. Sebagai sumber kehidupan masyarakat

3. Sebagai kemampuan untuk nilai/pembanding

4. Sebagai kemampuan untuk membentuk nilai tambah

5. Sebagai pola perilaku

6. Sebagai warisan

7. Sebagai proses yang mempersatukan

8. Sebagai program mental sebuah masyarakat

9. Dalam perkembangannya fungsi budaya menjadi tolok ukur pelaksanaan nilai-nilai suatu kelompok atau organisasi pemerintah

10. Sebagai citra, kekuatan penggerak dan dan pengubah, nilai tambah, pola perilaku, dan mencapai tujuan bersama dan program mental menjadi dominan.

\section{Produktivitas Kerja}

Produktivitas kerja di pandang sebagai konsep, filosofis, merupakan pandangan hidup dan sikap mental yang selalu berusaha untuk meningkatkan mutu kehidupan. Dimana kehidupan hari ini harus lebih baik dari mutu kehidupan besok harus lebih baik dari hari ini. Pandangan hidup dan sikap mental yang demikian akan mendorong manusia untuk tidak cepat merasa puas, tetapi harus mengembangkan diri dan meningkatkan kemampuan. Pengertian produktivitas sebenarnya menyangkut aspek yang luas, yaitu modal (termasuk lahan ), biaya, tenaga kerja, energi, alat, dan teknologi.

Secara umum, produktivitas merupakan perbandingan antara keluaran (output) yang dicapai dengan masukan (input) yang diberikan. Produktivitas juga merupakan hasil dari efisiensi pengelolaan masukan dan efektifitas pencapaian sasaran. Efektifitas dan efisiensi yang tinggi akan menghasilkan produktifitas yang tinggi.
Menurut Siagian (2002) produktifitas kerja merupakan kemampuan memperoleh manfaat dari sarana dan prasarana yang tersedia dengan menghasilkan keluaran yang optimal, bahkan kalau mungkin maksimal. Kemampuan yang dimaksud dalam definisi tersebut tidak hanya berhubungan dengan sarana dan prasarana, tetapi juga berhubungan dengan pemanfaatan waktu dan sumber daya manusia.

Menurut Blecher dalam Wibowo (2007) produktivitas kerja adalah hubungan antara keluaran atau hasil organisasi dengan yang diperlukan. Produktivitas dapat dikuantifikasikan dengan membagi keluaran dengan masukan. Menaikan produktivitas dapat dilakukan dengan memperbaiki rasio produktivitas, dengan menghasilkan lebih banyak keluaran atau output yang lebih baik dengan tingkat masukan sumber daya tertentu.

Produktivitas menurut Heijrachman (dalam Muzaini, 2012) dapat diartikan sebagai suatu sikap mental yang selalu mempunyai pandangan bahwa mutu kehidupan hari ini harus lebih baik dari mutu kehidupan hari ini. Secara sederhana produktivitas organisasi dapat diartikan terwujudnya sasaran atau tujuan dari suatu organisasi dengan cepat dan tepat dengan menggunakan berbagai sumber daya yang ada.

Jadi produktivitas dalam organisasi kerja yang dihasilkan adalah perwujudan tujuannya, maka produktivitas berhubungan dengan suatu yang bersifat materil dan non materil, baik yang dapat dinilai maupun tidak dapat dinilai dengan uang. Kemudian pada dasarnya produktivitas kerja mencakup sikap yang memandang hari depan secara optimis dengan penuh keyakinan bahwa kehidupan ini harus lebih baik dari hari kemarin hasilnya, artinya ada suatu peningkatan kepada arah yang lebih baik dan sempurna. 


\section{METODE PENELITIAN}

\section{Objek Penelitian}

Objek dalam penelitian ini adalah pengaruh budaya kerja terhadap Peoduktivitas kerja pegawai Sekretariat DPRD Kabupaten Pesawaran yang beralamat di Jalan Raya Kedondong Desa Way Layap Kecamatan Gedong Tataan Kabupaten Pesawaran. Penelitian dilakukan pada bulan Mei 2017 s.d. Juli 2017.

\section{Metode dan Teknik Pengumpulan Data}

Dalam penelitian ini jenis data yang diperlakukan adalah :

a. Data Primer

Data primer merupakan data dasar yang akan diperoleh langsung tanpa perantara orang atau lembaga lain sebagai pihak ketiga. Data primer ini diperoleh dengan wawancara melalui responden dengan menggunakan daftar pertanyaan.

\section{b. Data Sekunder}

Data skunder merupakan data yang diperoleh melalui orang lain yang berhubungan dengan permasalahan yang dipecahkan. Data sekunder ini diperoleh melalui cara studi dokumenter yaitu mengumpulkan dan mempelajari brosurbrosur serta dokumen organisasi.

Langkah-langkah pengumpulan data yang penulis lakukan dengan mengadakan penelitian lapangan yaitu Penelitian yang dilakukan di Kantor Sekretariat DPRD Kabupaten Pesawaran, adapun teknik yang digunakan dalam pengumpulan data adalah dengan :

1. Observasi, yaitu mengadakan survey atau pengamatan langsung kelokasi penelitian.

2. Interview atau wawancara, yaitu mengadakan tanya jawab langsung dengan pegawai pada Kantor Sekretariat DPRD Kabupaten Pesawaran.

3. Dokumentasi, yaitu mengumpulkan dan mencatat dokumentasi yang relevan.

4. Kuisioner, yaitu membuat pertanyaan yang berhubungan dengan varibael penelitian.

\section{Sampel dan Populasi}

Menurut Sugiyono (2007) Populasi adalah wilayah generalisasi yang terdiri dari objek atau subjek yang mempunyai kualitas dan karakteristik tertentu. Jumlah pegawai Sekretariar DPRD Kabupaten Pesawaran sebanyak 19 pegawai. Menurut Arikunto (2006) sampel adalah sebagian atau wakil populasi yang diteliti. Apabila subjek kurang dari 100 orang maka pengambilan sampel semuanya, apabila lebih dari 100 maka diambil $10-15 \%$ atau $20-25 \%$ tergantung dari kemampuan peneliti dilihat dari waktu, tenaga dan dana, sempit luasnya wilayah pengamatan dari setiap subjek, karena hal ini menyangkut banyak sedikitnya dana, besar kecilnya resiko ditanggung oleh peneliti, untuk meneliti yang beresiko besar, sampel yang diambil besar hasilnya akan baik. Keseluruhan pegawai sebagai sampel, dikarenakan jumlah Pegawai Sekretariat DPRD Kabupaten Pesawaran sebanyak 19 pegawai maka penulis mengambil seluruh pegawai untuk dijadikan sampel.

\section{Metode Analisis Data}

Analisis kualitatif adalah analisis yang menggambarkan secara rinci, dengan interpretasi terhadap data yang diperoleh melalui pendekatan teoritis. Dalam hal ini adalah untuk menyederhanakan data ke dalam bentuk yang lebih mudah dibaca dan diinterpretasikan melalui pendekatan teori, kemudian dideskripsikan atau dijelaskan. Analisis statistik deskriptif dalam penelitian ini akan dilakukan dengan mendeskripsikan 
semua data dari semua variabel dalam bentuk distribusi frekwensi. Data yang diperoleh dari hasil angket untuk masingmasing variabel menggunakan Skala Likert, dimana alternatif jawaban responden diberikan skor 1 sampai dengan 5, selanjutnya nilai-nilai dari jawaban responden dijumlahkan berdasarkan bobot nilai.

Analisis kuantitatif ialah metode analisis dengan angka-angka yang dapat dihitung maupun diukur, dan dalam prosesnya menggunakan alat bantu statistik. Statistik sendiri merupakan cara-cara ilmiah yang digunakan untuk mengumpulkan, mengolah, menganalisis, dan menginterpretasikan data berupa angkaangka, kemudian menarik kesimpulan atas data tersebut, dimana data tersebut disajikan dalam bentuk tabel, grafik, atau gambar (Algifari, 2003).

Persamaan Regresi Linear Sederhana menentukan persamaan regresi linear sederhana untuk X :

$$
Y=a+b X+e
$$

Keterangan:

$$
\begin{aligned}
& \mathrm{Y}=\text { Produktivitas kerja } \\
& \mathrm{a}=\text { Konstanta } \\
& \mathrm{b}=\text { Koefisien regresi } \mathrm{X} \\
& \mathrm{X}=\text { Budaya kerja } \\
& \mathrm{e}=\text { Faktor kesalahan }
\end{aligned}
$$

Untuk mengetahui besarnya pengaruh, penghitungan koefisien korelasi tersebut kemudian dilanjutkan dengan Rumus Koefisien Determinasi atau Koefisien Penentu (KP):

$$
K P=(r)^{2} x 100 \%
$$

Untuk menguji secara hipotesis secara parsial digunakan Uji t dengan rumus :

$$
t_{\text {hitung }}=\frac{r \sqrt{N-2}}{\sqrt{1-r^{2}}}
$$

Keterangan:

$$
\begin{array}{ll}
\mathrm{t}_{\text {hitung }} & =\text { Nilai } \mathrm{t} \\
\mathrm{r} & =\text { Koefisien Korelasi } \\
\mathrm{N} & =\text { Jumlah responden }
\end{array}
$$

Kriteria untuk Uji $t$ adalah sebagai berikut :

a) Jika $t_{\text {hitung }}>t_{\text {tabel }}$ maka Ha diterima dan Ho ditolak.

b) Jika $t_{\text {hitung }} \leq \mathrm{t}_{\text {tabel }}$ maka Ha ditolak dan Ho diterima.

\section{HASIL DAN PEMBAHASAN}

\section{Analisis Kualitatif}

Data yang diolah dari item angket 1 sampai 10 dproyeksikan kedalam prosentase jawaban. Berdasarkan hasil angket budaya kerja yang terdiri atas indikator Etos Kerja, Workacholism, Etika Kerja dan Anggapan Dasar tentang Kerja diperoleh hasil sebagai berikut : Sebanyak 9 responden $(48,95 \%)$ menjawab sangat setuju, 7 responden $(36,84 \%)$ menjawab setuju dengan budaya kerja pegawai sekrtariat DPRD Kabupaten Pesawaran dan sisanya sebanyak 3 responden $(14,21 \%)$ kurang setuju pencapaian budaya kerja selama ini.

Berdasarkan hasil angket produktivitas kerja yang terdiri atas beberapa indikator diantaranya efektivitas kerja dan efesiensi kerja diperoleh hasil sebagai berikut : ratarata Sebanyak 8 responden $(41,58 \%)$ menjawab sangat setuju, sebanyak 8 responden $(42,11 \%)$ setuju dengan produktivtas kerja pegawai sekretariat DPRD Kabupaten Pesawaranselama ini, dan sisanya sebanyak 3 responden $(16,32 \%)$ menjawab kurang setuju dengan produktivitas kerja pegawai sekretariat DPRD Kabupaten Pesawaran. 


\section{Analisis Kuantitatif}

Hasil perhitungan uji reliabilitas terhadap instrumen penelitian variabel budaya kerja dan produktivitas kerja menunjukkan adanya reliabel (kesesuaian) baik antara item pertanyaan maupun totalitas. Hasil menunjukkan bahwa cronbach's alpha total untuk variabel budaya kerja sebesar $0.952>0,632$, sedangkan cronbach alpha untuk variabel produktivitas kerja sebesar 0,954 >0,632, jadi dapat dinyatakan bahwa seluruh kuisioner adalah reliabel.

Hasil dari penghitungan statistik regresi linier sederhana pengaruh Budaya kerja terhadap produktivitas kerja pegawai koefisien arah regresi antara budaya kerja terhadap produktivitas kerja pegawai sebesar 0,514. Dengan demikian, persamaan regeresinya adalah $\mathrm{Y}=20,192+$ $0,514 \mathrm{X}$. Persamaan regresi tersebut terlihat bahwa pengaruh budaya kerja terhadap produktivitas kerja pegawai adalah searah (positif) yang mengandung arti bahwa setiap kenaikan budaya kerja 1 satuan akan diikuti dengan kenaikan produktivitas kerja pegawai Sekretariat DPRD Kabupaten Pesawaran sebesar 0,514 satuan.

Pengujian pengaruh budaya kerja secara parsial terhadap produktivitas kerja pegawai Sekretariat DPRD Kabupaten Pesawaran, penulis menggunakan uji statistic $\mathrm{t}(\mathrm{uji} \mathrm{t})$. Apabila nilai $\mathrm{t}$ hitung $>\mathrm{t}$ tabel maka Ho ditolak dan Ha diterima. Sebaliknya apabila nilai $\mathrm{t}$ htung $<$ nilai $\mathrm{t}$ tabel maka Ho diterima dan Ha ditolak. Nilai t hitung variabel budaya kerja yaitu 2,485 dengan konstanta 2,240 pada $t$ tabel dengan db 19 dan taraf signifikan 0,05 diperoleh 1,729 karena $\mathrm{t}$ hitung $>\mathrm{t}$ tabel maka $\mathrm{Ha}$ diterima. Signifikasi variabel budaya kerja adalah 0,039 yang berarti probabilitas 0,039, karena probabilitas kurang dari 0,05 maka Ha diterima. artinya budaya kerja berpengaruh positif terhadap produtivitas kerja pegawai Sekretariat DPRD Kabupaten Pesawaran.

Seberapa jauh variabel budaya kerja menjelaskan variabel produktivitas kerja dapat dilihat dari nilai koefisien determinasi $(R \quad$ Square). Dari hasil perhitungan diketahui bahwa Kontribusi ( $R$ Square) sebesar 0.266 artinya sebesar $26,6 \%$ variasi perubahan variabel produktivitaskerja mampu dijelaskan oleh variabel budaya kerja sedangkan sisanya sebesar 73,4 \% lagi dijelaskan oleh variabel lain diluar dari variabel penelitian ini. Berdasarkan hasil pengujian hipotesis budaya kerja berpengaruh positif dan signifikan terhadap produktivitas kerja pegawai.

Budaya kerja merupakan hal yang sangat mempengaruhi meningkat dan menurunnya keberhasilan seseorang dalam melaksanakan tugas yang telah diberikan padanya. Selain akan memotivasi seorang pegawai tersebut untuk giat dalam menghasilkan produktivitas kerja, budaya kerja yang baik juga akan menjauhkan seorang pegawai dari bermacam resiko yang mungkin bisa mengancam posisi kepegawaiannya tersebut.

Melihat begitu pentingnya peranan Budaya Kerja, maka dapat dilihat besarnya pengaruh Budaya Kerja tersebut terhadap sumber daya manusia yang ada di suatu instansi pemerintahan tersebut, budaya kerja tersebut dapat dilihat dan diamati oleh peninjauan dari luar maupun dari dalam instansi tersebut. Hal ini dapat dirasakan dari suasana kerja yang membedakannya dengan instansi lain. Dan pada akhirnya dapat berpengaruh terhadap produktivitas kerja yang dihasilkan.

\section{KESIMPULAN DAN SARAN}

\section{Kesimpulan}

Berdasarkan hasil penelitian dapat disimpulkan bahwa hasil pengujian hipotesis pengaruh Budaya kerja (X) 
terhadap Produktivitas Kerja (Y) secara parsial menunjukan bahwa Nilai $\mathrm{t}$ hitung variabel budaya kerja yaitu 2.485 dengan konstanta 2.240 pada $\mathrm{t}$ tabel dengan $\mathrm{db} 19$ dan taraf signifikan 0,05 diperoleh 1.729 karena $\mathrm{t}$ hitung $>\mathrm{t}$ tabel maka Ha diterima. Signifikasi variabel budaya kerja adalah 0.039 yang berarti probabilitas 0.039 , karena probabilitas kurang dari 0,05 maka Ha diterima. artinya budaya kerja berpengaruh positif terhadap produtivitas kerja pegawai Sekretariat DPRD Kabupaten Pesawaran. Kontribusi ( $R$ Square) sebesar 0.266 artinya sebesar $26,6 \%$ variasi perubahan variabel produktivitaskerja mampu dijelaskan oleh variabel budaya kerja. Berdasarkan hasil pengujian hipotesis budaya kerja berpengaruh positif dan signifikan terhadap produktivitas kerja pegawai.

\section{Saran}

Adapun saran yang diajukan peneliti adalah sebagai berikut :

1. Budaya kerja hendaknya dikelola dalam menjalankan pekerjaan bagi seluruh pegawai yang berguna agar pencapaian target kerja dapat terelisasi.

2. Produktivtas kerja pegawai hendaknya didasarkan atas kewajiban dan tugas yang diemban sehingga mempermudah pekerjaan dan pegawai hendaknya dalam bekerja berorientasi pada hasil pekerjaan.

\section{DAFTAR PUSTAKA}

Arikunto, S. 2002. Prosedur Penelitian Suatu Pendekatan, Praktek, Edisi Revisi V, Cetakan Kedua Belas. Jakarta: Rineka Cipta.

Hasibuan, Mulayu S. P. 2007. Manajemen Sumber Daya Manusia. Edisi Revisi. Jakarta: Bumi Aksara.
Heidjrachman dan Suad, Husnan. 2002, Manajemen Personalia. Jakarta: Badan Penerbit. Fakultas Ekonomi (BPFE).

Kepmenpan Nomor :25/KEP/M.PAN/04/2002 Nilai Dasar Budaya Kerja Organisasi Pemerintah. Jakarta.

Permenpan RB Nomor 39 Tahun 2012 Tentang Pedoman Pengembangan Budaya Kerja. Jakarta.

Permenpan Nomor : Per/01/M.PAN/01/2007 Tentang Evaluasi Pelaksanaan Pengembangan Budaya Kerja Pada Instansi Pemerintah. Jakarta.

Sedarmayanti.2009. Sumber Daya Manusia dan Produktivitas Kerja. Bandung: CV. Mandar Maju.

Siagian Sondang P., 2002. Manajemen Sumber Daya Manusia, Jakarta : PT Bumi Aksara.

Triguno, 2004. Budaya Kerja : Menciptakan Lingkungan Yang kondusif Untuk Meningkatkan Produktifitas Kerja. Jakarta: PT. Golden Trayon Press.

Wibowo. 2007. Manajemen Kinerja. Jakarta: PT. Raja Grafmdo Persada.

Yeni Dwi Rochmawati , 2014 Pengaruh Budaya Kerja Terhadap Produktivitas Kerja Karyawan Pada PT Bank Jatim Cabang Lumajang di Lumajang. 